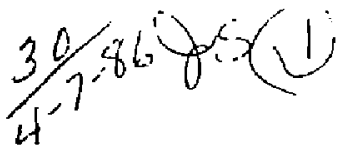

$$
\begin{aligned}
& I-25659 \\
& \text { (1) DY } 27.4 \% 1 \\
& \text { UCID--20667 } \\
& \text { DE86 } 008789
\end{aligned}
$$

\title{
RESEARCH ON GAS TRANSPORT IN CHIMNEYS \\ A Progress Report
}

Joseph R Hearst

March 18, 1986

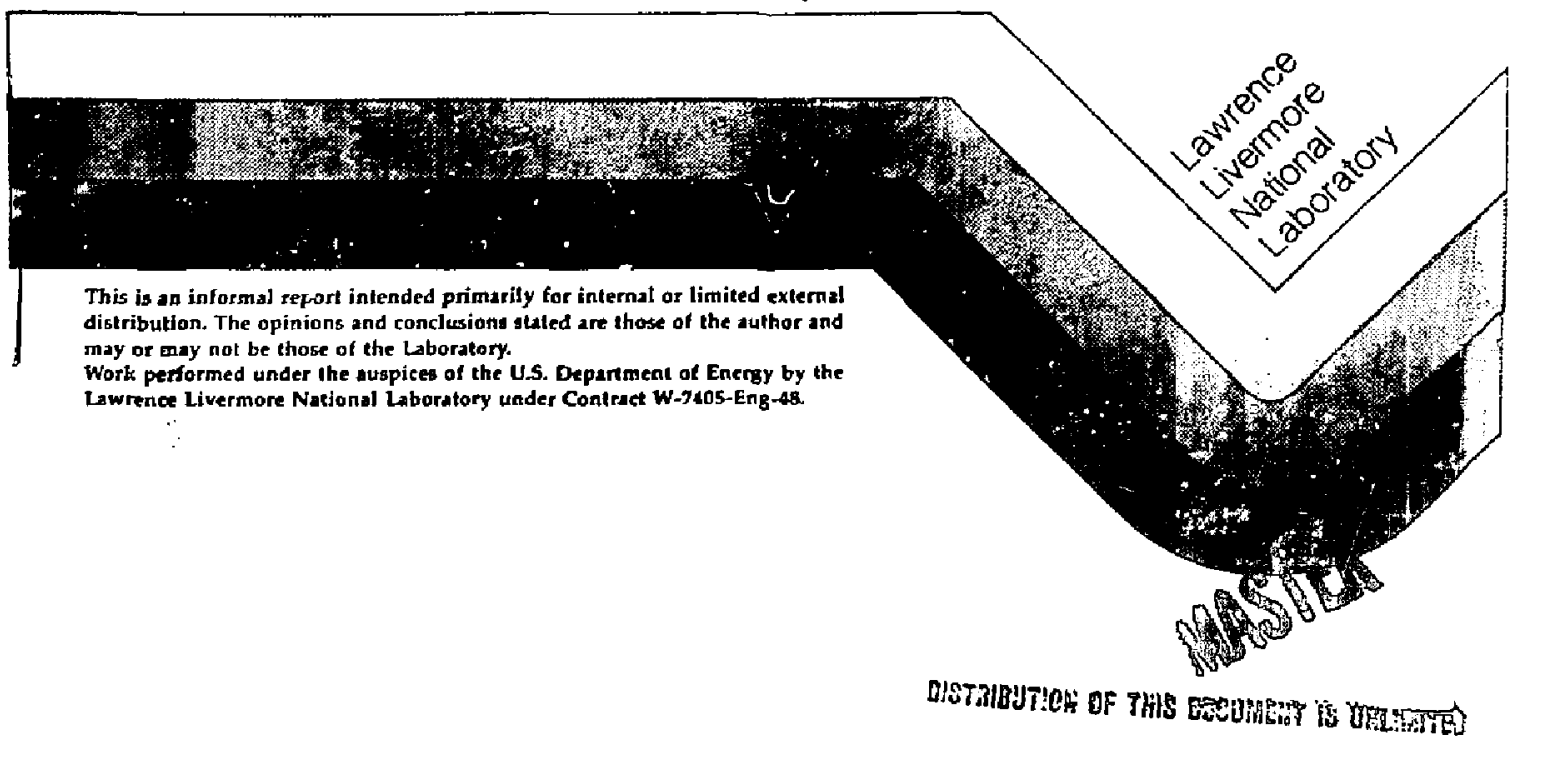




\section{DISCLAIMER}

This report was prepared as an account of work sponsored by an agency of the Uniled States Governmen. Neither the Unjted States Government nor any agency thereol, nor any of their employees, makes any warranty, express or implied, or assumes any legal liability or respensibility for the accuracy, completeness, or usefulness of any infonmation, apparsius, product, or process disclosed, or represents that its use would nol infringe privately owned rights. Reference herein to any specific commerciai product. process, or service by trade name, trademark, marufacturer, or otherwise does aol necessarily constitute or imply its endorsement, recomrendation, or favering by the Unied States Govermment or any agency thereof. The views and opinions of authors expresszd herein do not necessarily state or reflect those of the United States Government or any agency thereof. 


\title{
A Progress Report
}

\author{
Joseph $R$ Hearst
}

\section{ABSTRACT}

The results of the AGRINI and TIERRA exper iments have led us so study three general topics: collapse phenomenology, $\mathrm{CO}_{2}$ content measurement. and gas transport in chimneys. Our results so far are fragmentary, but we have been able to come to some tentative conclustons: if a layer of strong materlal between depths of 24 and $32 \mathrm{~m}$, and perhaps some relatively strong matertal deeper, may have caused tine AGRIMI crater shape. This layer was absent at the nearby LABAF and CROLDIE events. He were unable to locate the layer with a surface penetrometer or surface selsmic methods, but it may be posstble to measure strength us depth in situ by examining the penetration depth of a projectile. 2) We can probably improve our knouledge of the in situ $\mathrm{CO}_{2}$ content by calibrating a comerctal carbon/oxygen logging system for NTS conditions. 3) It is possible to measure the response of the gas in a chimney to changes in atmospheric pressure. There can be significantly different gas transport in chimneys with the same pressure response. depending on the porosity and the distribution of the porosity. It is possible to perform an inexpensive experiment to study the gas transport in an existing chininey.

\section{INTRODUCTION}

AGRINI was a low-yfeld event detonated at a depth of 320 in in hole U2ev on farch 3i. 1984. A very deep (approx 70-m). narroy, bottle-shaped crater was formed about $1.75 \mathrm{~h}$ after detonation (Hudson et a 1; 1985). Figure $?$ shous a schematic of the crater.

Radloactive gas bas detected by a gas-sampling system fmediately after collapse (Smith. 1985). The bottom of the sampling hose is thought to have been at a depth of betueen 170 and $220 \mathrm{~m}$. Prampt sampling hoses have usually broken fairly high in the hole upon collapse. Gas is ordinarily 
pouped from these hoses after subsidence. but a significant anount of radioactivity has rartiy been observed in the gas. It has naver before been observed as soon after collapse and as high in the chlmey as 12 was at A6RIMI. The gas was $73 \times \mathrm{CO}_{2}, 7 \mathrm{X}$ hydrogen, and $20 \mathrm{X}$ air, at a pressure of 12.2 psia. The uncertainty in pressure is thought to be about 1 psia. Andyses indicate that the gas was not in commulcation with the couty throughout the 20-day sampling time.

About $9 \mathrm{~h}$ after detonation, unexpected sadioactivity was detected at the surface, apfarently coming from the crater. During the follouing $26 \mathrm{~h}$, about $1700 \mathrm{Ct}$ (predominantly isotupes of xenon) were determined to be released (0swa 1d, 1984). There is considerable uncertainty in these times. Atmospheric pressure at the surface was comparable to that observed downhole. In fact, surface pressure (F/g. 2, Soula, 1984) was greater than (but whin the uncertainty of) reported subsurface pressure. Consequent $7 y$. there is no evidence that high gas pressure orove the activity to the surface.

Hudson et al. (1985) have shown that the emplacement hole and its steming did not contribute to the release. Radiation levels above the deep soft plug at 225 i rematned at background through the termination of recording at collapse. In addition, there vas no negative pressure that would indicate lass of steming before collapse. Therefore, we may conclude that if we are to seek an explanation of the release, te must look somethere other than the emplacement nole.

Besides the release. there are two obrious olfferences between the AGRINI observations and those on "normal," satisfactorily contained events. Wever before has there been such a deep collapse crater. And never before has radiodctive gas been abserved so high in the chimey so soon after collapse.

Since gas was observed with a hose uhose cpening yas at a depth betueen 170 and $220 \mathrm{~m}$. and the crater was a most $70 \mathrm{~m}$ deep, the gas had to trayel a maximum of 100 to $150 \mathrm{n}$ to estape. It seems logical to look to this combination of circumstances for an explanation of the AGRIAI release. It is unltkeiy that te ull ever be able to predict a stintlar situation, but by 
Investigating the individual elements of the comblnation, we wy be able to understand the transport of gas through a chimey.

So our investigation shouid center on three questions:

i. What caused the unique crater shape?

2. Why did the gas get as high as $110 \mathrm{~m}$ deep in the chimey so soon after collapse?

3. How did the gas get from about 170 m deep in the chimey to the surface?

These questions Jed us to study three general toples:

1. Collapse phenomenology:

There is evidence that some of the alluvium above AGRINI yas unusually strong. He should study collapse phenomenology to learn whether this strong aliuvium could have caused the unusual crater shape.

2. $\mathrm{CO}_{2}$ content measurement:

The observed $\mathrm{CO}_{2}$ content at AGRIHI was within expertence. He measure $\mathrm{CO}_{2}$ content from cuttings, usually taken at ten foot intervals. There is good evidence that although each measurement may be quite accurate, the cuttings may not represent a grod average of the $\mathrm{CO}_{2}$ content of the medium. Hore representative measurements of $\mathrm{CO}_{2}$ content might nave shown that in fact the $60_{2}$ at AGRIHL was higher than reported, and therefore could have tieen a significant factor in transport of activity to the surface.

3. Gas transport in chimneys:

It is passtble that the shallow gas in the AGRIN1 chimey tas caused by unusual gas transport during collapse. He need to better understand gas transport during collapse. It is also quife pos5ible that transport after collapse sas more rapid than usual. The chtniney rubble may have been more permeable than in ordinary Yucca fiat chimneys, or there may have been blocks of rubble, those edges provtoded easter transport paths than usual. He need to investigaie gas transport propertles of chimeys. 
In partlculer. we are studying the differences between AGRIMI and two neatby "noras1." successfully contained events with siatlar reporied $\mathrm{CO}_{2}$ content, yiela, and scaled depth of burlal: crowole in u2fe, 450 from U2ev, which had a falriy normal crater, 81 in diameter and 13 deep: and LABAN in U2ff, $3 \mathrm{~km}$ from U2ey, which had a steep-sided "cookle-cutter" crater. 42 in diameter and 38 deep. This should heip us understand which tharactertstics of AGRIHI were normal and which were anomolous. The remainder of this report will descr tbe the studies ve have siarled, and their results to date.

\section{COLLAPSE PHENOMENOLOGY}

Hudson et a1. (1985) point out that the medlum property most relevart to crater shape is probably shear strength. To determine the strengh of the near-surface alluvium at AGRINI, a shallow exploratory hole, UE 2ev, was or llled with an auger $113 \mathrm{~m} \mathrm{SW}$ of U2ev, to a tepth of $36 \mathrm{~m}$. An examination of sampies from the hole indicated a partially to well-indurated calcite. cemented sandy conglomerate zone extending from 24 to $32 \mathrm{~m}$ in depth.

A twa-dimenstona) Lagranglan TENSOR calculation of AGRINI (Hudson et al. 19851 was carried out using the observed near-surface propertles, and its results were compared wh those of an identical calculation using "normal" near-surface alluvium properties. In the normal calculation, the shear strength of the alluvium between depths of 0 and $50 \mathrm{~m}$ was zero at zero mean stress and $0.52 \mathrm{HPa}$ at $0.35 \mathrm{MPa}$ mean stress. and increased to a maximum of 1.1 F.Pa. The tenstle strength was zero. In the AGRIHI calculation, tuo matertals were used above $50 \mathrm{~m}$. In the Indurated zone between 24 and $32 \mathrm{~m}$, shear strength increased from $0.5 \mathrm{MPa}$ at 2 ero mean stzess to $11 \mathrm{hPa}$ at 10 APa mean stress, and then increased to a maxtmum of $34 \mathrm{MPa}$. Tenstle strength was $0.36 \mathrm{MPa}$. In the rest of the region above $50 \mathrm{~m}$, shear strength increased from zero at zero mean stress to $10 \mathrm{MPa}$ at $10 \mathrm{MPa}$ mean stress, and then to a maxtmum of $21 \mathrm{MPa}$. Tensile strength $\forall a s$ zero in this region. Bath sets of properties represent the lower bound of measured strength data.

In the normat calcutation, there was shear fallure to the surface during the outgoing wave, and tenstle fatlure upon spall. In the AGRINI calculation, there was no shear fallure above $50 \mathrm{~m}$, the high-shear-sirength 
reglon, and no tensile fallure between 32 and $50 \mathrm{~m}$, the high-tensilestrengih region. The colculated and weasured free-surface veicitios compared we 11. These results suggest that if the actual strengths are simtlar to those used in the calculation, then the near-surface matergal was strong enough to sustain little damage from the stress wave. Conseguer.tiy. the AGRinl crater shape vas at least partiy due to the relativeiy highstrength, near-surface alluvium.

Since it appeared that the near-surface strong layer might be important to crater shape, we orllled simtlar exploratory holes near LABAN and CROAOIE (Hagoner, 1985). At LABAH (U2ff) there vere rare beds of calctte-cemented sediment. At CROHOIf (U2fe) there were several thin zones of calcitecemented sediment. There was no avidence of materlal with greater strength at the straight-sided LABAH crater site than at the normal CRONDIE crater site. In fact, If anything there was more calcite-cemented material at CrOWDIE than at LABAN. Conseguently we could not assoctate the presence or absence of cemented layers with crater shape at these sites.

Because the strong layer seems to be of considerable importance, it would be very useful to be able to locate such a layer from the surface before drfliting an exploratory hole. Two methods for locating the layer were trled. Reflection seismology was attempted at AGRINI (Hauk. 1996). The shallow depth required very close station spacing, and consequently the surface wave was so strong that reflectlons from the strong layer could not be observed. Therefore the layer could not be located. It may. notever, be possible to improve the technique with further attempts.

A truck-mounted penetrometer (Blouin and Noe). 1985) was tr fed at one site in Area 3 and etght siles in northern Yucca flat. The force on the $t \mathrm{p}$ of the penetrometer cone and the force along the side of the cone are measured as functions of depth. A schematic of the tip is shoun in Fig. 3 . The penetrometer is forced into the ground by a steel tod until the truck. weighing about $18,000 \mathrm{~kg}$, begins to ifft off the ground, or until the rad buckles (not desirable). Plots of tip stress us depth for several Vucca flat sites are show in Fig. 4. In Area 3 the penetrator uas able to penetrate more than $2 B$ m before the truck began to ifft. There tas only one northern yucca flat site, U2ff, at which the penetrator advanced more than 
78 Defore the truck began to 11ft. At several 51 tes penetrabion was less than $10 \mathrm{~m}$. At v2ev, oxiaum penetration was about $15 \mathrm{~m}$. unich is above the incurated layer. Furthermore, we were unable to find any characteristic differences between the U2ev site and other sites in Northern Yucca flat at tire shaliou depths that could be studied.

The RGRIMI calculation used a much thicker strong layer than that observed in the fleld, and Thtgpen (1984) potnts out that a thick strong layer is requlred for an arch to form above a subsurface chimey. Consequentiy. it would oe highly deslrable to be able to measure shear strength, or eyen unconfined compressive strength, vs depth in place.

Two methods were tried for such a measurement. The first used of the force on the tip of the truck-mounted penetrator and was not successful (Hearst and fickinnts, 1985). The other used penetration oi a projectile. and appears quite promising. Figure 5 shous depth of penetration of a fiut-nosed $80 \mathrm{-g}$ projectlle at a velority of $530 \mathrm{~m} / \mathrm{s}$ vs unconfined compressfve strength in tuff. He are now developing a more sophtsticated syscem for testing improved versions of this method at the surface: If the method continues to appear successful we will adapt it for dounhole use.

Eventuaily it will be necessary to make a more complete calculational mudel of collapse phenomena. A beginning has been made. Thigpen and Rambo 17985: have used a finite-element method to show that creep is a possible meihanism for cavity collapse. This method may eventually lead to a nore detalled understanding of collapse. He are also beginning tork to simulate caytty and chimey collapse with a centrifuge; experimencs 4171 probably not take place before FY 87.

\section{CARBON DIOXIDE CONTENT}

Tabie I shows the veight fraction of $\mathrm{CO}_{2}$, obtatned from three different sources. for the working point (WP) regtons of our three events. The igrst colum is $\mathrm{CO}_{2}$ as gtven for the up interval in the site Characteristics Sumary. For AGRINI this value uas obtained from cuttings; for LABAN and CROWOIE It was obtained from sldegall samples. In all three cases, the average was a numerical ayerage of all of the sample data in the 
MP interva1. The second colum is the sam average of a second set of samis: for AGRinI new splits of the cuttings, for LABAf and CROMDIE. samples from the cuttings. The third calum comes from postshot gas analys $1 \mathrm{~s}$, assuming that the masured total eass of $\mathrm{CO}_{2}$ was evolved from 1200 tonnes of rock per klloton of yleld.

The agreement between the first two columins is within thetr standard deviations, and so is satisfactory. But constoer fig. 6, a plot of $\mathrm{CO}_{2}$ der ived fiom both sidewall samples and cuttings from U2ff. The regiop used In Table 1 is indicated by arrows; there is gaod agreement between sideuall sample and cutting data in that region. Had the MP been $30 \mathrm{~m}$ higher, hovever. it would have been in a reglon of great disagrement between sldevall sample and cutting data. If we had been evaluaiting that region today. since we no longer take sidewall samples, we would have used the results from cuttings: $0.035 \pm 0.18$. had sidevall samples been used instead, the result would have been $0.06 \pm 0.031$-an unacceptable value of $\mathrm{CO}_{2}$ ! (Fur thermore, in this region there are individual $\mathrm{CO}_{2}$ values as wigh as 0.1 .1 Had the up been another $75 \mathrm{~m}$ higher. the result from cultings would have been $0.041 \pm 0.012$, and that from sldewall samples would have been $0.011 \pm 0.008$. In that case the old method wourd have indicated satisfactory $\mathrm{CO}_{2}$ content, whereas the current method would have shoun it to be marginal. Disagreements this large between averages of sidetall samples and cuttling values of $\mathrm{CO}_{2}$ are common at U2fe and U2ff.

The $\mathrm{CO}_{2}$ values from gas sampling fall within the standard deviations of the sample data in two of the three events: the result is very different for LABAW. The chotce of rock mass, 1200 tonnes per klloton, represents an

Table I. Measured wetght fraction of $\mathrm{CO}_{2}$

$\begin{array}{clll} & \mathrm{CO}_{2} \text { from } & \text { Second value of } & \mathrm{CO}_{2} \text { from } \\ \text { Event } & \text { Site. Char. Sum. } & \mathrm{CO}_{2} \text { from samples } & \text { gas sampling }\end{array}$

$\begin{array}{llll}\text { AGRIN! } & 0.025 \pm 0.017 & 0.022 \pm 0.014 & 0.023 \\ \text { LABAN } & 0.033 \pm 0.007 & 0.040 \pm 0.006 & 0.016 \\ \text { CROHDIE } & 0.004 \pm 0.003 & 0.009 \pm 0.008 & 0.007\end{array}$


ayerage obtained from gas sapling on five recent events (Saith, 1986.) Had we used a different vilue. the event for mich agretaent was bad uould hove changed, but the fact of disagiesment vould not.

The combination of significanic disagreement netween individual $\mathrm{CO}_{2}$ values at wany horizons. as exenplified in $\mathrm{Fig}$. 6. Alsagreenent betyeen average values, and disagreement betveen values from r.yk sampling ano gas sampling leads us to belteve that a mere reliable, or sore representative. measurenent of $\mathrm{CO}_{2}$ content is very desirable. Recent evidence (Axe irod, 1986) even questions the rellabllity of the laboratory $\mathrm{CO}_{2}$ measurements on individual samples. We are torking on two methods of peasuring $\mathrm{CO}_{2}$ content vs depth.

The carbon/oxygen $\log$ is a standard comerclal method for measuring carbon in ruck (Hearst and Helson, 1985, D. 274.) it contalns a neutron generator and a gamma-ray detector. Its primary output, the carbon/oxygen $(C / 0)$ ratio is the ratio of the gamma ray count rates in two wirdous, one bracketing the energy of gama ra!s resulting from inelastic neutron scattering from carbon, the otler the energy of gama rayz produced by inelastic neutron scattering from oxygen. Several correctlons are applied to the count rates from each windcu before the $c / 0$ ratyo is formed. As is usual with comercial linging equipment. the system avallable to us is designed for small-diameter water-fllled holes. whereas we ordinar 1 ly wse large-diameter air-filled holes.

the have begun a program to callbrate a comerclal logging syctem for HTS situations. have found that the $c / 0$ ratlo is sensitive not only to the carbon content of the rock, but aiso to the water content and the gap between the instrument and the wall of the hole. Pretiminary results indicate that both of these effect: are falriy linear, and it is ilkely that He will be able to correct for them. Figure 7 shous a plot of the $6 / 0$ ratio vs weight fraction $\mathrm{CO}_{2}$ in a test faclitty with no gap and ith a $6.3-\mathrm{cm}$ gap. As the figure shows, if the gap is knoun, $\mathrm{CO}_{2}$ can be measured to better ihan $\mathbf{0 . 0 2}$.

He are yorking with Los Alamos National Laboratory to make a detalled study of the effect of uater content. gap, and the chemical composition of 
the rack on the weasured c/0 ratio. He are also tryting to decide on athe best way to oodify the equipent to binimize the effect of the gap. and to measure the gap so that we can wake a good correction. We we on the pracess of butlding a new test facllity, and if should be completed dur ing fr 86.

For several years we have been forking ina a professor at the University of Washington to use infrared reflection spectroscopy to ceasure $\mathrm{CC}_{2}$ content in samples on-iine. Th's would permit us to obtain and measure the $\mathrm{CO}_{2}$ conlent of many samples automatlcaily in the fleld, and thus obtain more reprasencative resuits. The prolect has not been proceeding rapidiy. and the $(/ D)$ lag appears more pramising; it is unilkeis that we will conilnue the project beyand iY 86 .

\section{GAS TRAMSPORT IN CHIMANEYS}

Our interest lit gas tricisport is caused not only by the results of AGRIHI, hut aiso by those of TIERRA and KhPELLI. In the case of the latter everis, leaks occurod orer long perlods, several to winy days after execution. Le ara considering seveial questions:

How is gas transfiorted during collapse? Hou did it get so high in the AGRINI chimney so soon afte: coltapse? How is gas transported after collapse? How do chlinney properties affect transport? Hou do medtuts properiles affect transport? How can we heasure the relegant properties?

It is belleved that the dominant method of gas transport during collejse is the displacement of gas by rubble. There 15, however, no direct ubservation of this displacument, nor 15 there lthely to be. He are planning smali-scale laberatory experimenis at S-CuBED to give us some qualitative understanding of the displacement phenomenon, but at present ve have no results.

It appears that the AGRINi leak occurred during an eplsode of atmospheric low pressure (Hudson et a). 1985). Figure 2 shous the situation. The uncertalnty in the subsurface pressure does not permit us to state whether the subsurface cressure yas in fact greater than atmospheric 
pressure. There is evidence (Raschke, 1995) that the TIERRh leak rate was correleated with low pressure. Consequently, we are studying the effect of changes In ateospheric pressure on the transmission of gas through chimeys.

In a hoaggeneous isotroptc aedlum, the hydraulic diffusivity a can be determined by comparing the pressure history at the surface to that at some depth in the wedium (Hanson, 1984, 1986), such that

$$
\text { Q }=k P_{s} / \mu p, d P / d t=\alpha\left(\partial^{2} P / \partial z^{2}\right) \text {. }
$$

where a is the diffusivity. $P_{s}$ is the mean pressure, $k$ is the permeability, $w$ is the viscosity of the gas, and $p$ is the medium. porosity. Figure 8 (Nitson and Peterson, 7986) shows the effect for an ideallzed case.

The postshot gas sampling hole has been used as a source of the subsurface pressure measurements for several HTS chimneys. Figure 9 shous the pressure measured at U2ev compared with that measured at the surface. To determine the diffusirtty, one performs a serles of on:-dimensional forward calculatlons, using the surface pressure history and varying the diffusivity, unt 11 one obtatns the best match to the subsurface pressure history. Figure 10 shows the final calculated subsurface pressure history compared with the measured history.

Results so far have not been consistent with observed leaks, as is shoun in Table 2 .

Jable 2, Measured chimney diffusiutties.

Hole

$$
\text { Diffusivity }\left(m^{2} / h r\right)
$$

U2ev

2288.

U2ff i88.

Uafe 9370

u19ac 3599 . 
These results wy be caused by probleas with the postshot hole. The algnal at U2ff appears to indicate that the postshot hole is blocked. In the case of Jafe. the casing of the postshot hole is very short, and there et ther be fractures to the surface. far from the chinney, or a leak around the casing. More data are needed before we can understand the situation.

It is possible to make similar analyses assuming layered media and treating the chimney as a medium different from its surroundings, but the results of the anaiyses are not greatly different from those using a one-dimensional analysis. He are continuing to develop analytical methods and improve our measurements.

The interpretation of the experiment in terms of diffusivity applies only for homogenous isotrople media. In fact, however, we are not interested in transmission of pressure, but rather in the transmission of radloactive gas. S-CUBED is studying the effect of "atmospheric pumping on gas transmission in various medla. N11son and Peterson (1986) have compared two situatlans--crude approximations to TIERRA--in which an experiant litue that described above would give the same result.

In the first situation. a vold of about the same volume as the TIERRA cavity was connecteo to the surface through a $200-m$ column of overburden materlal having a permeablitty of $350 \mathrm{D}$ and a porosity of 0.1 . This corresponds to a tiffusivity of about $60,000 \mathrm{~m}^{2} / \mathrm{hr}$ (a value measured at ulgac preshot.) a sinusoldal pressure wave wh a pertod of $100 \mathrm{~h}$ and a peak-to peak ampiltude of $1 / 30 \mathrm{~atm}$ was imposed at the surface. As the surface pressure decreased, the cavity gas rose in the chlmney. but because of the large pore valume in the chimney. the gas uas stored in the pores and never reached the surface. At the end of a half cycle, the surface pressure increased, and the gas returned to the cavity.

In the second situation, the chimney was replaced by a zero-porosity medium in thich the path to the surface conststed of a fracture neturor. Each fracture had an aperture of $1.7 \mathrm{~mm}$, and the fractures yere separated by 1 -m-thick blocks, so the effectlve porosity uas 0.017 . The pressure response uas identical to the first situation, but there yas far less pore volume in the chimey. Consequently. as the surface pressure decreased, the 
gas rose rapteity and reached the surface before the end of the first half cycle.

These two situatlons represent extreme cases, pure por ous peraeable nediun and pure fractures. In real chimeys there is likely to be a combination. S-Cubeo has performed a serles of laboratory experitonts indicating that in fact a combination of situations 107 resuli in an intermediale type of transmission of gas. Gas travels part of the say to the surface in the fractures during the first cycle. and then some is stored is in the porous medium adjacent to the fractures. Then on the nert cycle some of this stored gas continues towards the surface, This ratcheting mechanism continues unt11 gas reaches the surface. The experiments are continuing.

We plan to investigate gas transmission in the field by ingecting a very sma 11 amount of $\mathrm{SF}_{6}$ into postshot gas sampling holes and measuring the concentration at the surface as a function of time. Concentrations of $10^{-12}$ can be measured routinely. We will simultaneously compare surface and subsurface pressure. Thus, we w11 attempt to link pressure response and gas transport.

\section{CONCLUSIONS}

Our results so far are fragmentary:

1. The strong layer, coupled with relatively strong material deeper. may have caused the observed AGRINI crater shape.

2. The strong layer is essentially absent at LABAN and CROHDIE.

3. The strong layer at AGRINI could not be found by surface penetration or seismic reflection.

4. He have shown that it may be possible to measure strength vs depth by means of penetration of a profectile.

5. Calculations show that creep behavior is important in collapse initiation.

6. The commerclal carbon/oxygen log appears to be good enough that, yith corrections. It can improve our measurements of $\mathrm{CO}_{2}$ in place.

7. It is possible to measure the response of the gas in a chimney to changes in atmospheric pressure. 
6. There can be solificantly different gas transport in chimeys wh the same pressure resporise. depending on the porosity and the fisir butution of the porosity.

9. It is possible to do an inexpensive experinent to study the gas transport in an existing chimey.

\section{ACKNCHLEDGEMENTS}

This report could not have been written without the active cnoperation of Bllly Hudson. Clitif 01sen. John Rambo. Chuck Sintth. and Jeff Hagoner of LLML; Bob N1lsan of S-CUBED; and Jon Hanson of Hanson Associates. 


\section{REFERENCES}

Azelrod. H. . Laurence I, tvermore Matlonal Laboratory. Livermore. CA. Rellability of C02 Analyses, personal comanication. (1986)

Blouin. S. t.. and 3. S. Noe1. Electric Cone Penetration Testa in Nevada Test Site Tuffs and Alluyiuns, Applied Research Inc. Report, persond comunication. (1985)

Hanson, J. S.: Barometr ic Pressure Transient Testing Applications at the Hevada Test Stte: Formation Pereability Analysis. Final Regor?. Terratek. Salt Lake City, UT, Report UCRL-15699 (1985)

Hanson. J. S. Baroinetrfic Pressure Irans lent Jesting Applications at the Mevada Test Site: Muclear Chimney Analysts. Hanson Assoctates, Salt Lake City UT. Beport, UCRL 15770 (1986)

Hauk, T., Laurence Livermore Hattonal Laboratory, Livernore. CA. personal cosmuntcation, (1986)

Hearst. J. R, and H. B. Hckinais. "h Comparison of Projectlle Penetration and a Cone Penetrometer ar Mpthods for Heasuring Tuff Strengtha: in Proc. $3 r$ d Symostum on Contatinment of Undercround Wuc lear explosions. loho fal1s, Sept. 9-13 1985. Lahr ence Liveroore Mational Laboratory, Livernore CA, CONF-850953.

Hearst. J. R, and P. H. Me1son; Mell Logging For Phystcat Properties. (Mc6rav-Hi11, Wew York, 1985)

Hudson. B. C., J. T. Rambo, J. L. Magoner, and H. E. Loury: 'AGRIMI Postshot Contasnment Report." in Proc. 3rd Symposium on Containment of Underground Huclear explosjons, Idabo falls, Sept, 9-13 1985, Lautence Liverinore National Labaratory. Livermore CA, COMF-850953. 


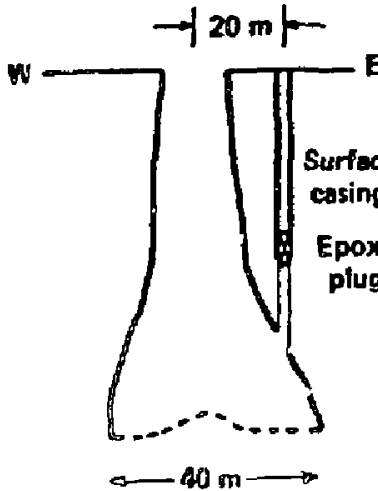

$$
\begin{aligned}
& -0 m- \\
& -10 m- \\
& -20 m- \\
& -30 m- \\
& -40 m-- \\
& -50 m-- \\
& -60 m- \\
& -70 m-
\end{aligned}
$$
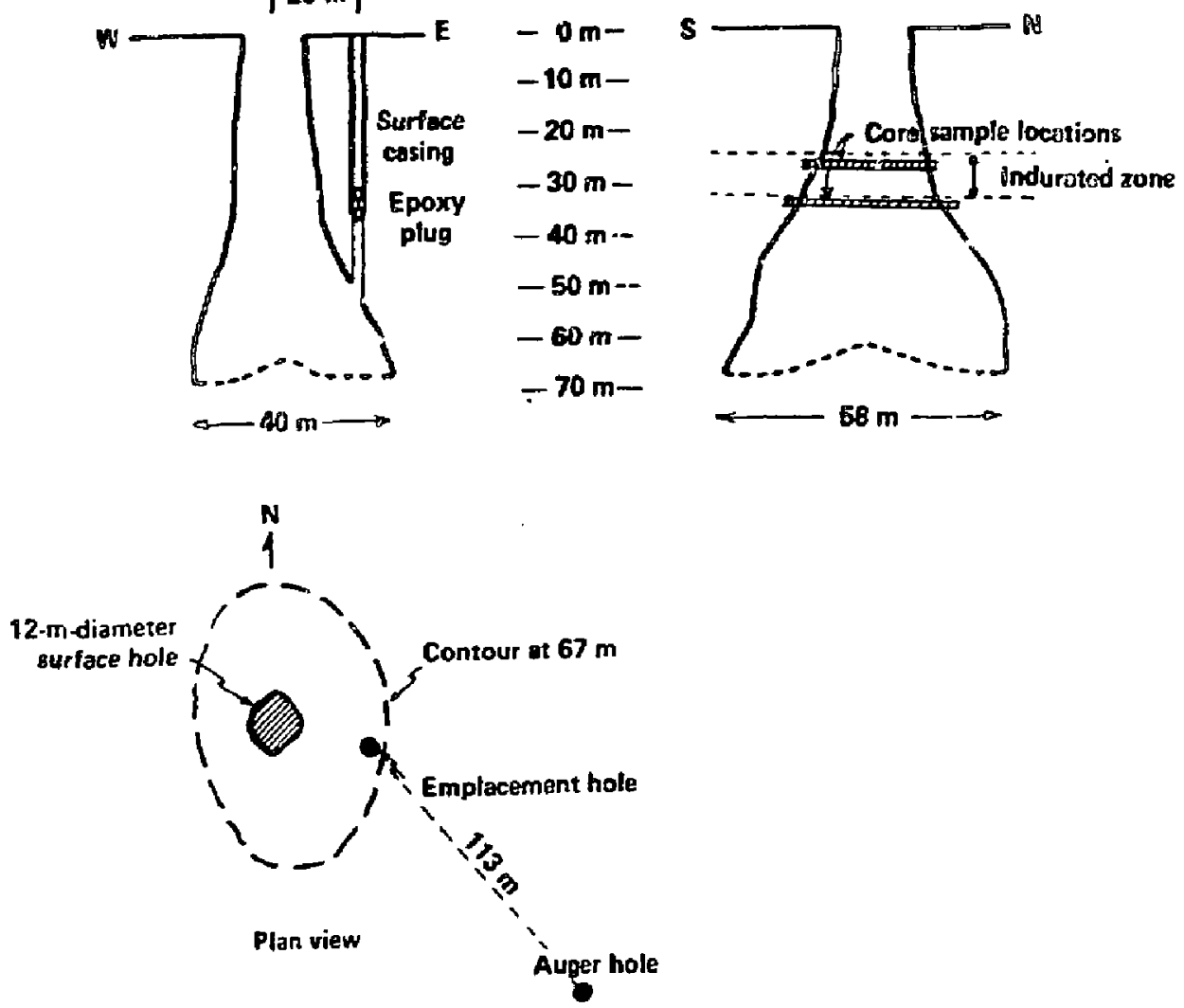

Figure 1. Scbematic of the AGRINI crater, including the indurated zone. 


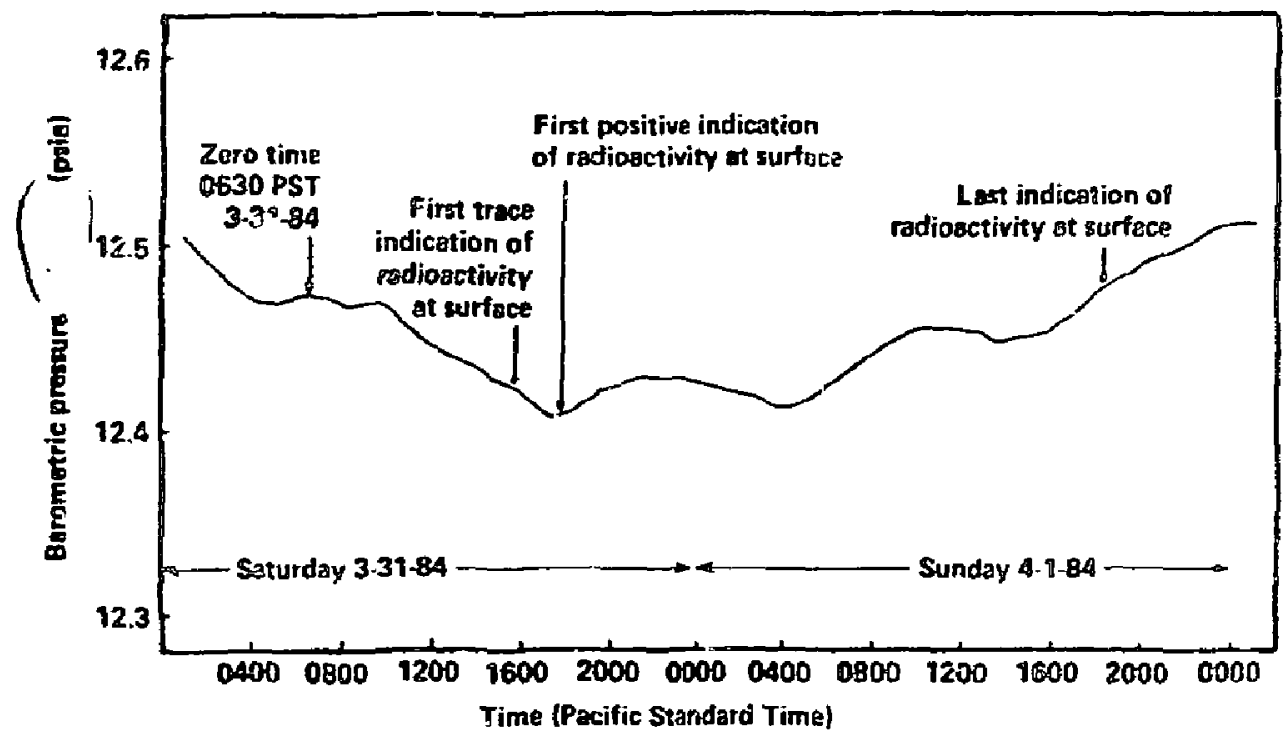

Figure 2 Release and atmospheric pressure histories. 


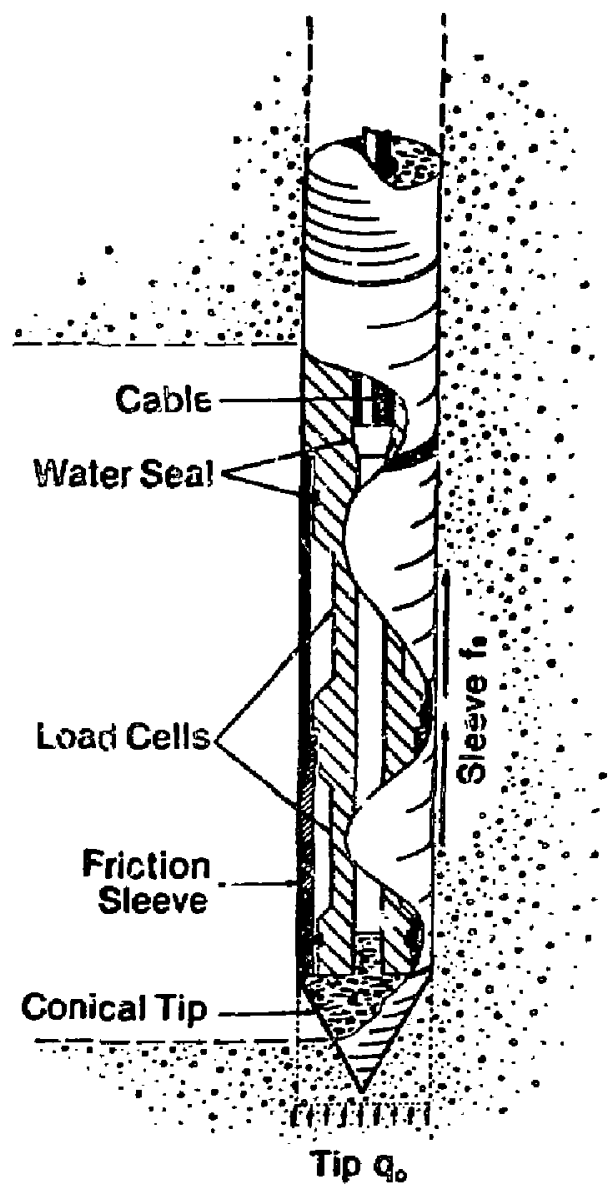

3. Schenatic view of ARR high-capacicy cone penetrome ter. 


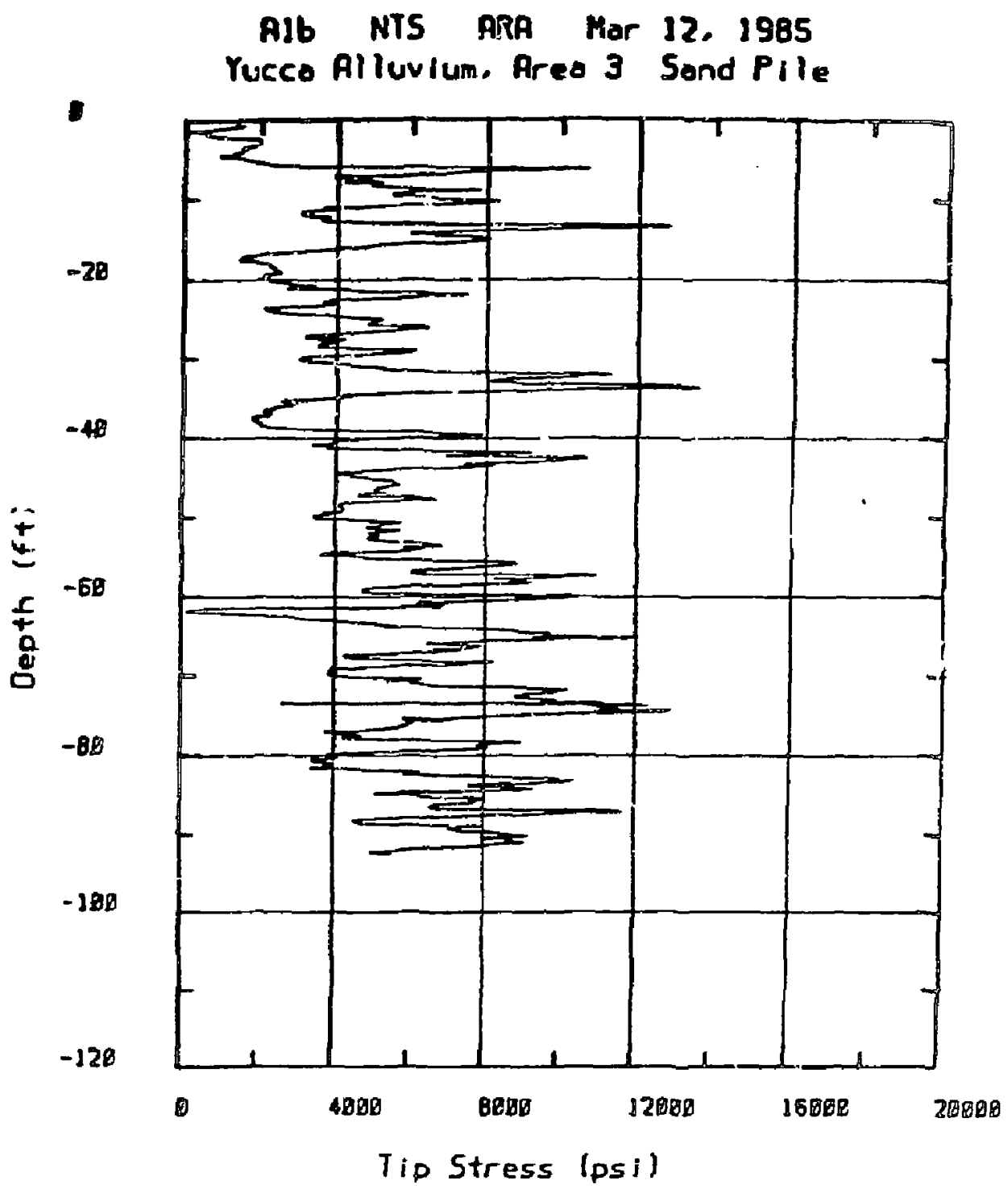

Figure 4a. Tip resistance vs depth in Area 3 sandpile. 


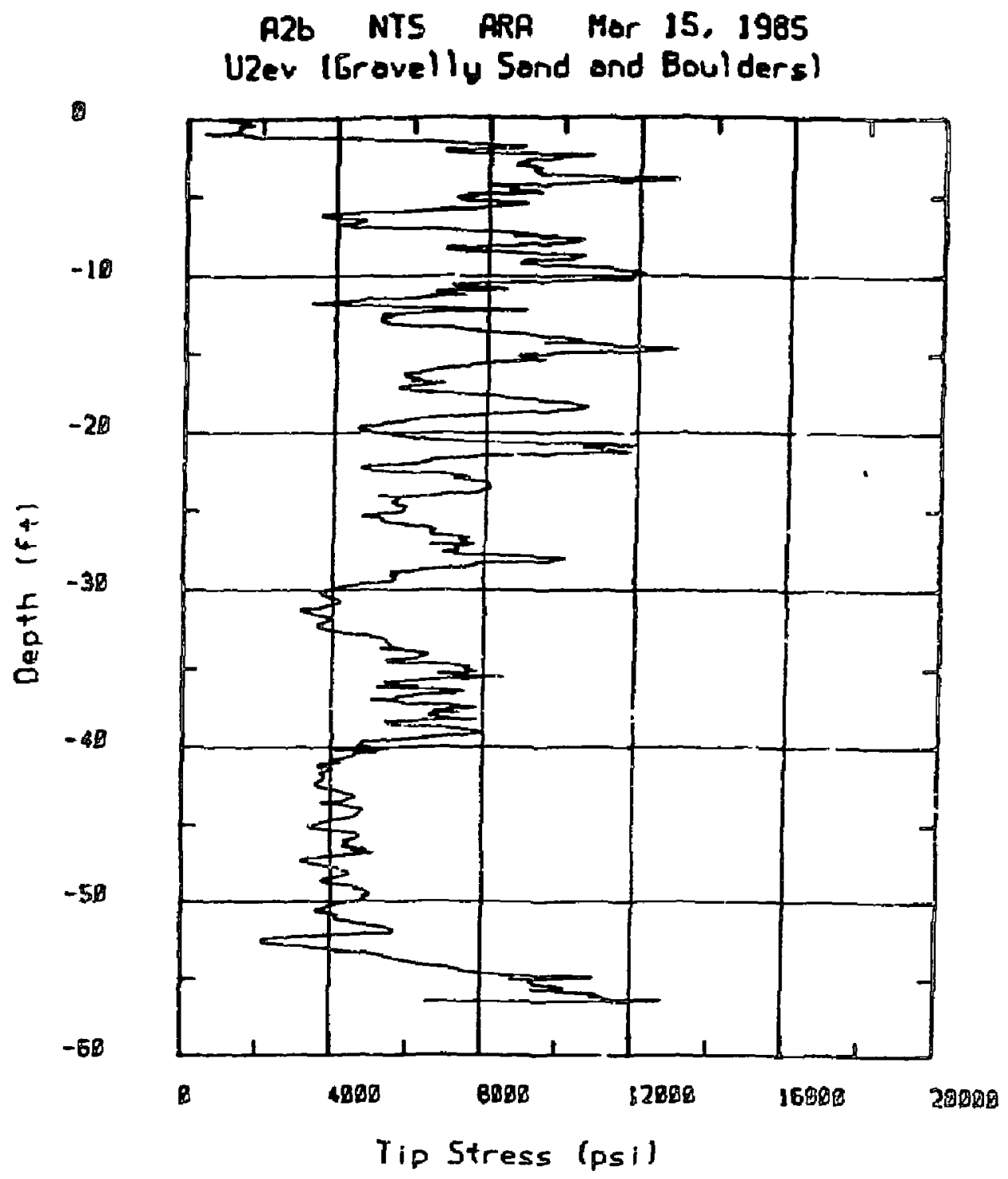

Figure $4 b$. Tip resistance vs depth at u2ev 


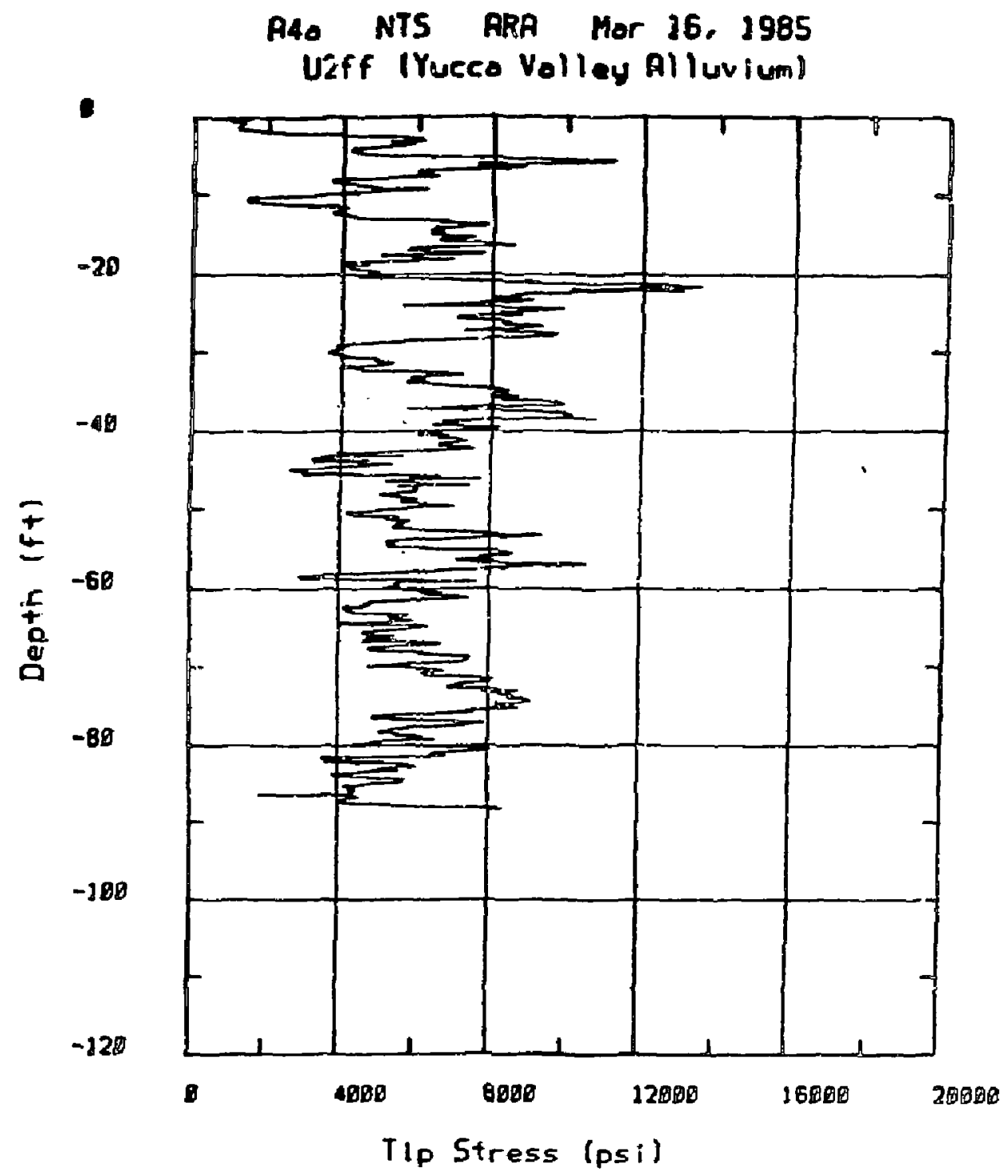

Figuie 4c. Tip resistance.vs depth at Uaff. 


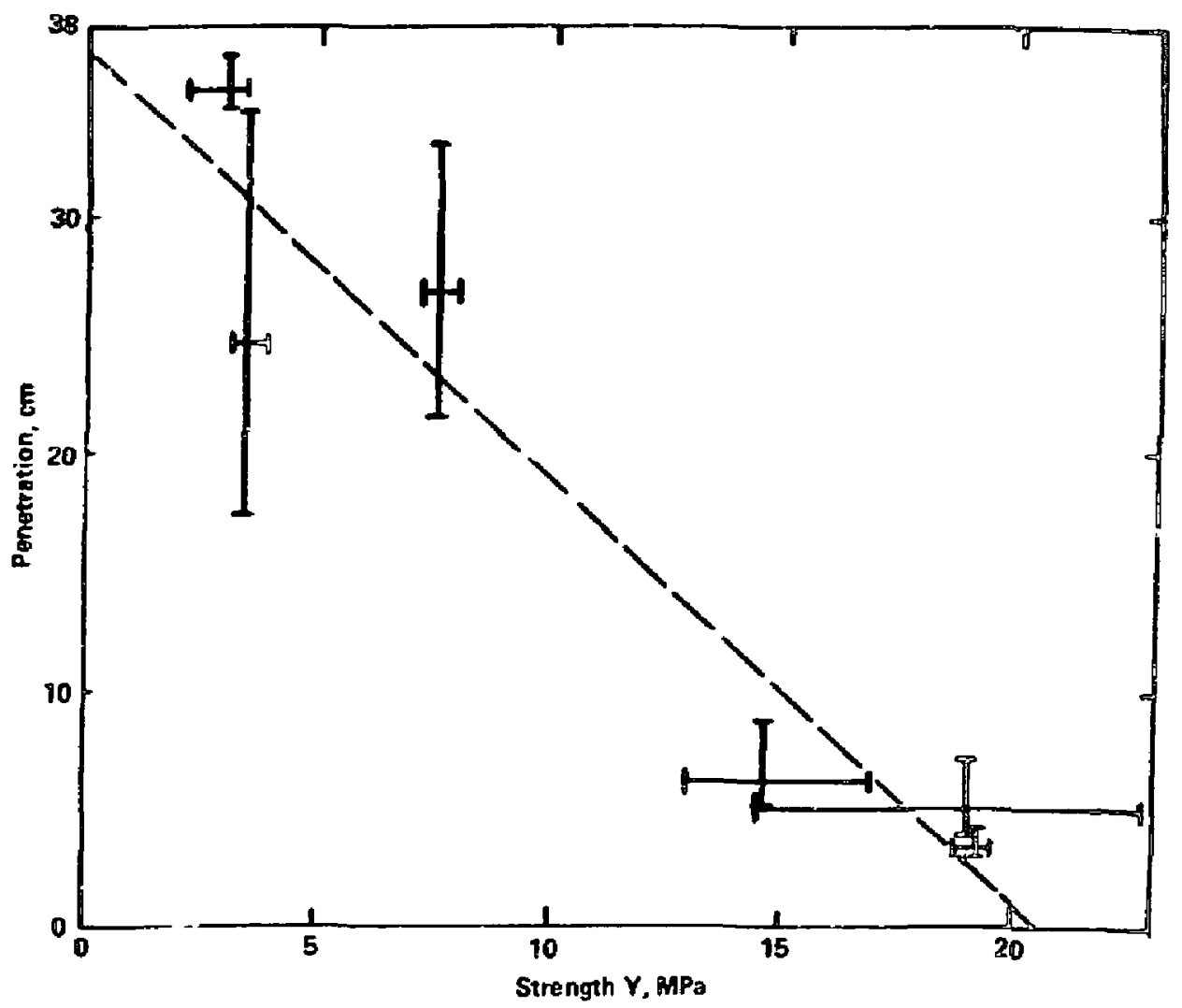

Fig. 5 . Depth of projectile penetration ws unconfined compressional strength. 


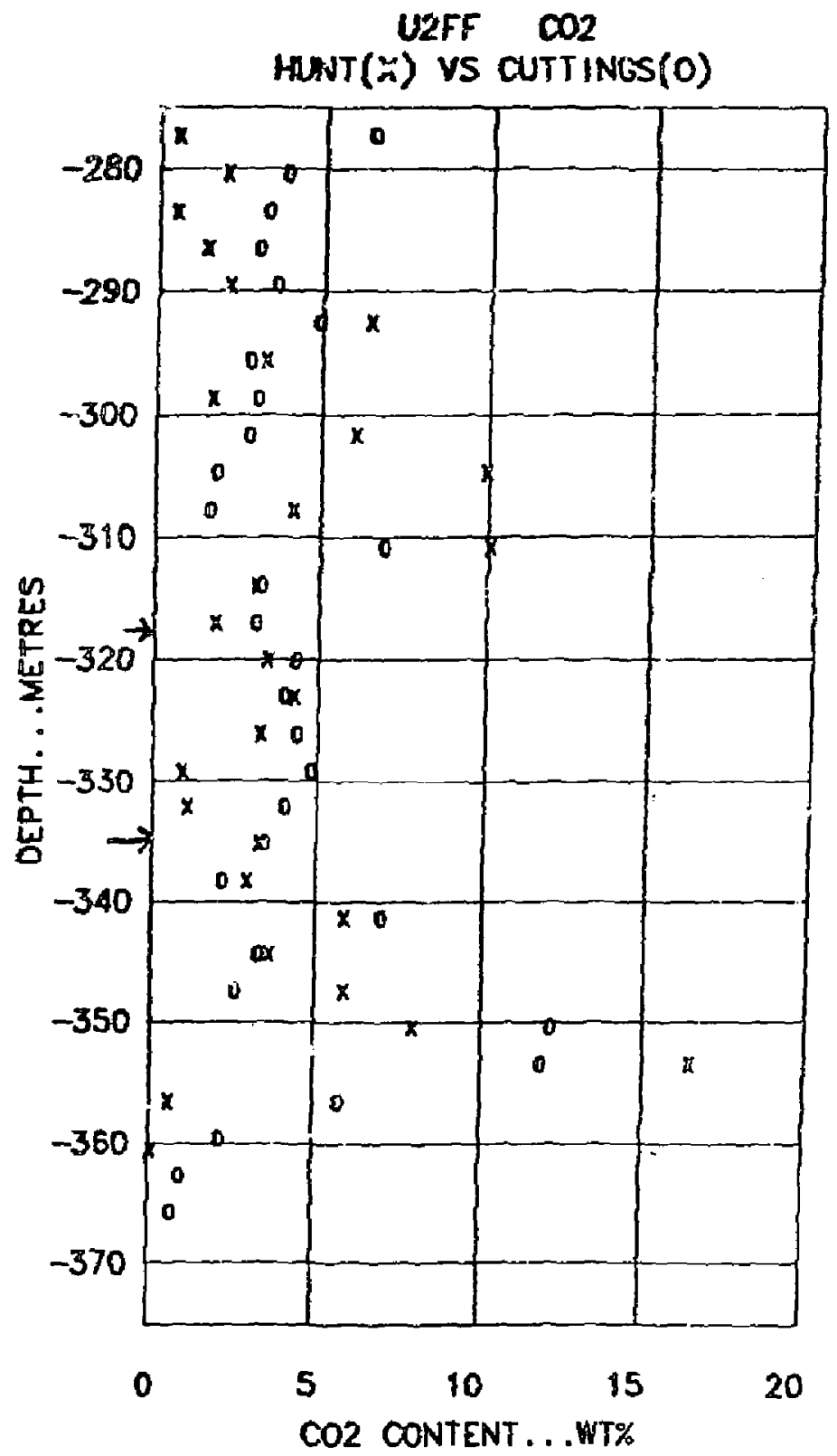

Figure 6. $\mathrm{CO}_{2}$ content from Hunt sidewall samples and cuttings at u2ff, 


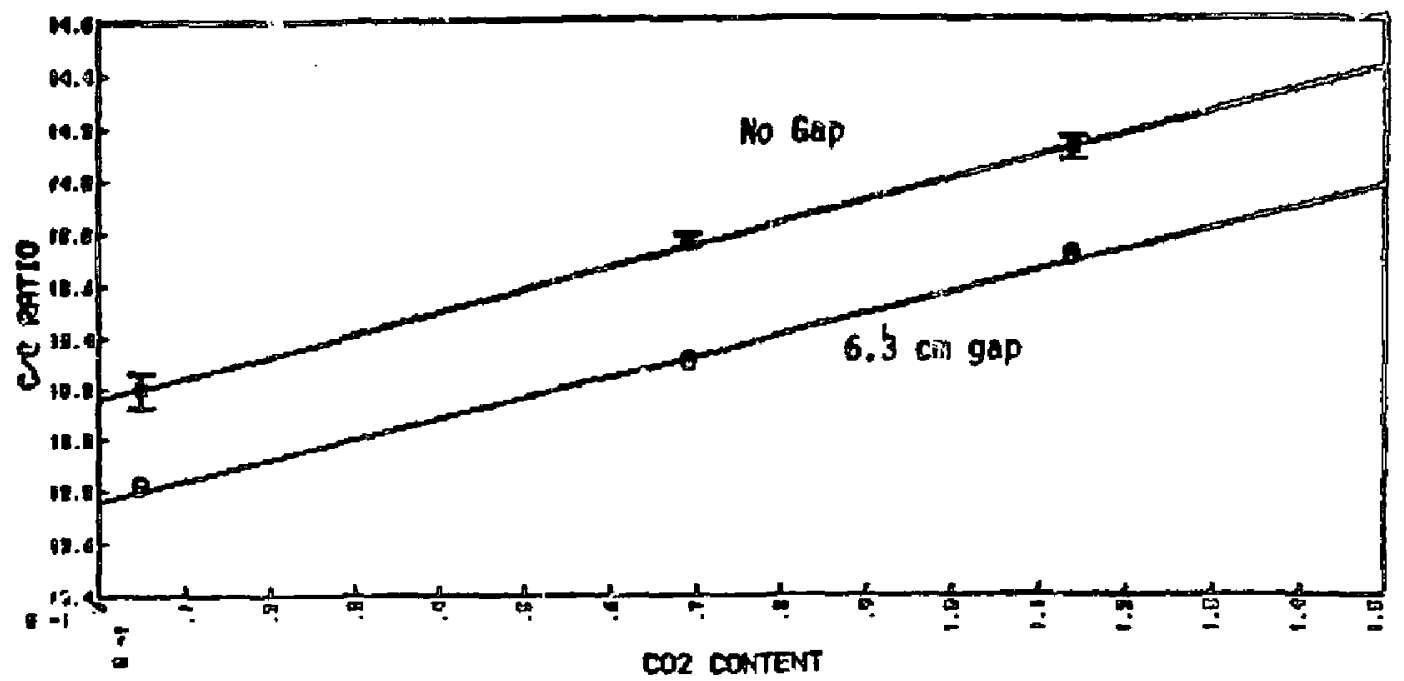

Figure 7. Resulis of preliminary calibration of a cumercial Carhon/0xygen loy.

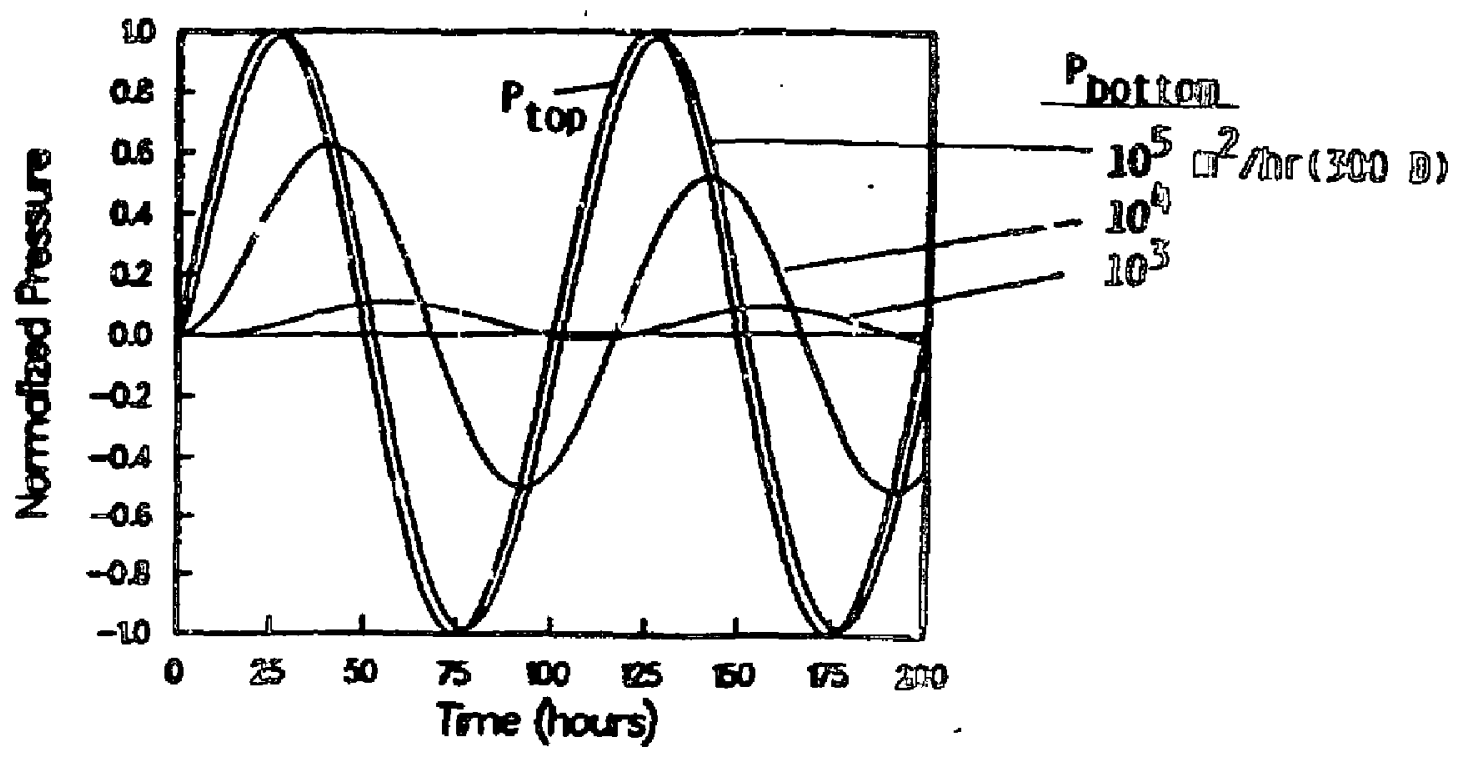

Figure 8. Idsalization of response of pressure at the bottom of a column with various values of diffusivity to changes in pressure at the top. 


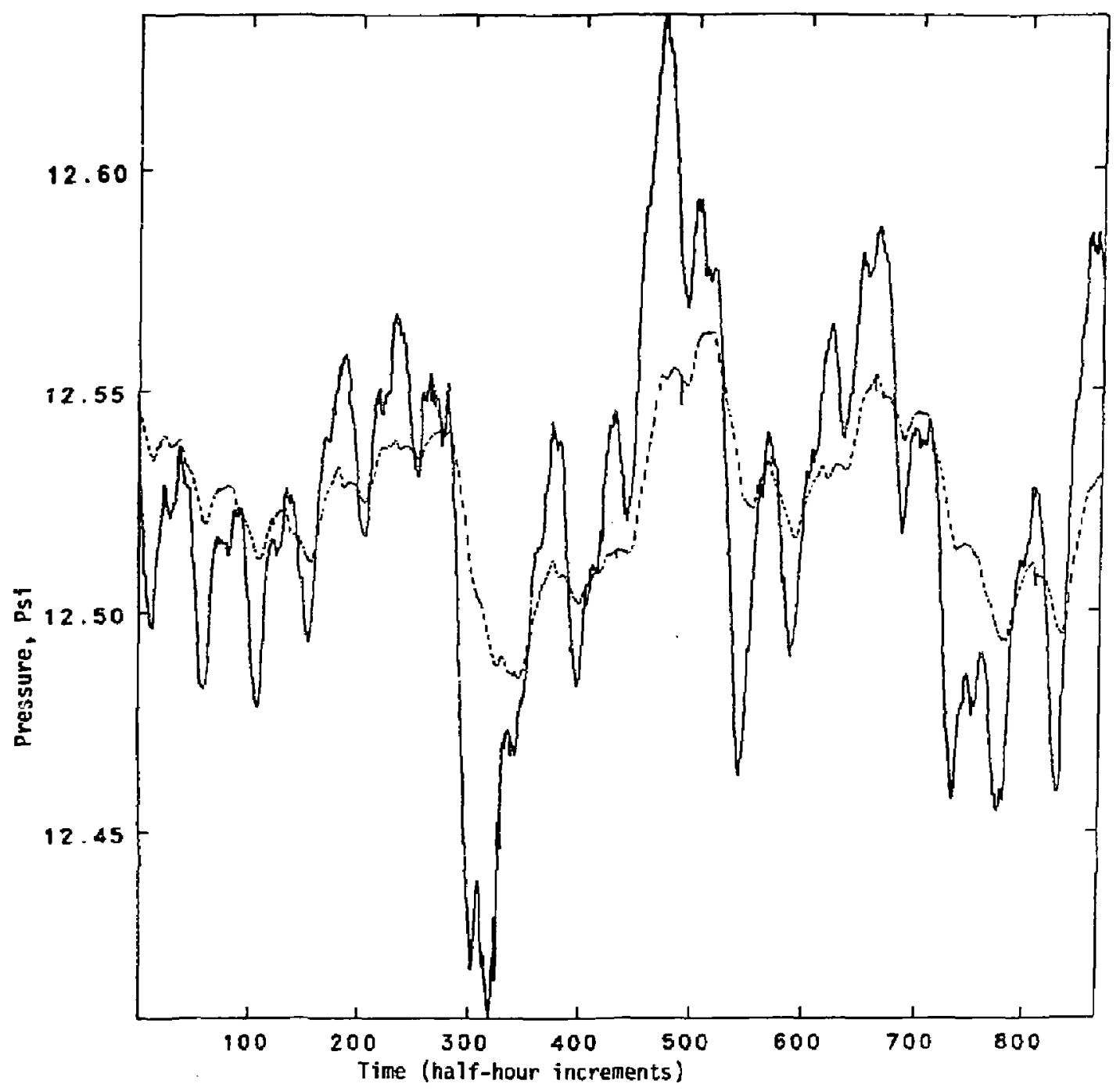

Figure 9. Surface (solid) and downhole (dashed) pressures recorded at the postshot gas-sampling hole U2ev-PS-la. 


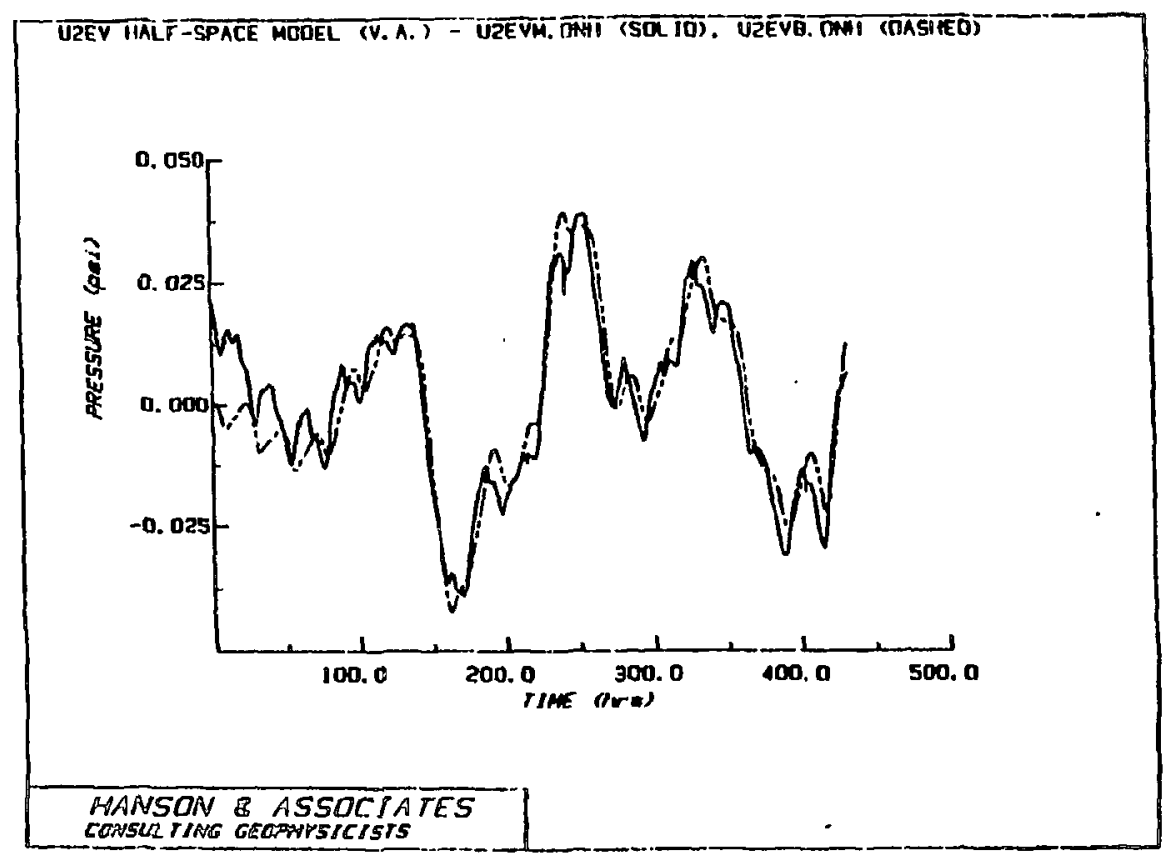

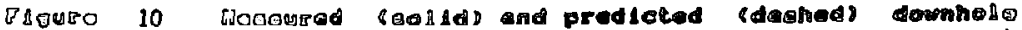
proOOHEO SOF WZOV. Inflnhto hal Dodod. 